\title{
Formula with Reduced Protein Content: Effects on Growth and Protein Metabolism during Weaning
}

\author{
IRENE E. AXELSSON, IRÉNE JAKOBSSON, AND NIELS C.R. RÄIHÄ
}

Department of Pediatrics, University of Lund, Malmö General Hospital, Malmö, Sweden

\begin{abstract}
A total of 20 healthy term infants between 4 and 6 months of age were randomly assigned to either a low protein formula (F1.3) containing $1.3 \mathrm{~g}$ protein $/ 100 \mathrm{ml}$ or a high protein formula (F1.8) containing $1.8 \mathrm{~g}$ protein/ $100 \mathrm{ml}$. Both formulas were isocaloric $(72 \mathrm{kcal} / 100 \mathrm{ml})$ and had a whey-casein ratio of 50:50. Ten control infants were breast-fed (BF). The mean protein intakes (including supplementary foods) were $1.9 \pm 0.3,2.6 \pm 0.2$, and $1.3 \pm$ $0.2 \mathrm{~g} / \mathrm{kg} / \mathrm{day}$, respectively. The mean concentrations of serum urea were $2.8 \pm 0.6$ (F1.3), $4.1 \pm 0.6$ (F1.8), and $2.2 \pm 0.8 \mathrm{mmol} / \mathrm{liter}(\mathrm{BF})$ at 6 months (F1.3 versus $\mathrm{BF}$, NS, F1.8 versus BF, $p<0.001$ ). The urine excretion of nitrogen was similar in the F1.3 and BF groups being 81 and $78 \mathrm{mg} / \mathrm{kg} / \mathrm{day}$. In the $\mathrm{F} 1.8$-group nitrogen excretion was higher, $138 \mathrm{mg} / \mathrm{kg} /$ day. Plasma concentrations of albumin, prealbumin, and transferrin were normal and similar in the groups. Weight gain was significantly higher in the F1.8 group, $22.8 \pm 1.7 \mathrm{~g} / \mathrm{kg} / \mathrm{wk}$ when compared to the F1.3 and BF groups, $19.9 \pm 3.9$ and $18.0 \pm 4.3(p<0.01)$, respectively. These data indicate that a decreased proteinintake from formula during weaning results in many indices of protein metabolism and growth more similar to those found in BF infants than when conventional follow-up formulas are used. (Pediatr Res 24: 297-301, 1988)
\end{abstract}

\section{Abbreviations}

Fl.8, high protein formula

Fl.3, low protein formula

BF, breast-fed

There is growing awareness that early nutrition may exert significant consequences later in life (1). We and others have previously demonstrated an excessive protein load in artificially fed infants during the first 3 months of life which is reflected in a metabolic response that is not consistent with that of BF infants $(2-4)$.

After 3 months of age, so-called "follow-up" formulas with a protein concentration between 1.8 and $2.5 \mathrm{~g}$ protein $/ 100 \mathrm{ml}$ are commonly used in Europe, although the protein requirements per unit body weight decreases with increasing age (5). We have recently shown a protein intake which is two to three times higher from such formulas when compared to that of $\mathrm{BF}$ infants $(6-8)$.

On the basis of these findings, a low protein formula $(1.3 \mathrm{~g}$ protein $/ 100 \mathrm{ml}$ ) was designed, which would hopefully produce

Received February 18, 1988; accepted April 20, 1988.

Correspondence Dr. I. Axelsson, Department of Pediatrics, University of Lund, Malmö General Hospital, Malmö, Sweden. growth and metabolic responses more comparable to those found in BF infants. In this study we have evaluated the growth and biochemical parameters in infants of 4-6 months of age, when feeding with a formula, containing $1.3 \mathrm{~g}$ of protein $/ 100 \mathrm{ml}$.

\section{MATERIALS AND METHODS}

Subjects. Ten BF and 20 formula-fed infants participated in a prospective study between the age of 4 and 6 months. The artificially fed infants were assigned randomly to one of two formulas containing 1.3 or $1.8 \mathrm{~g}$ of protein $/ 100 \mathrm{ml}$. The infants were recruited from 12 local Child Health Centers. All infants were appropriate for gestational age, born at term, healthy, and had normal anthropometrics (9) when randomized into the study. The BF infants were exclusively BF until the start of the study, when supplementary foods were introduced. The infants in the two formula groups were exclusively $\mathrm{BF}$ until 1 to 2 months of age. Then the feeding of the infants gradually changed from breast milk to formula. Between 3-4 months of age all infants received conventional standard formulas, which varied in protein content between $1.3-1.8 \mathrm{~g}$ protein $/ 100 \mathrm{ml}$.

The mothers came from good socioeconomic conditions. Written and verbal information regarding the study was given to the parents by the responsible doctor (I.A.). At 4, 4.5, 5, and 6 months the infants were examined at our ambulatory clinic.

Feeding and nutrient intakes. The amount of breast milk ingested over a 48 -h period was determined by weighing each infant before and after each feeding at 4 and 6 months of age. The mothers were instructed in the use of an automatic electronic weight balance. The precision stated by the manufacturer was $\pm 1 \mathrm{~g}$.

From the data of milk volumes, the protein and energy intakes were calculated based on the figure for mature human milk of $0.96 \mathrm{~g}$ protein per $100 \mathrm{ml}$ and $65 \mathrm{kcal} / 100 \mathrm{ml}$ as previously described (6). The artificially fed infants received a formula containing either $1.3 \mathrm{~g}$ of protein or $1.8 \mathrm{~g}$ of protein $/ 100 \mathrm{ml}$. Both formulas were isocaloric, $72 \mathrm{kcal} / 100 \mathrm{ml}$, and had a whey to casein ratio of 50:50. The formula powders were specially manufactured for the study by the Findus Company, Bjuv, Sweden, and delivered to the hospital with code numbers. The volumes of formula consumed by the infants was recorded by the mothers in milliliters for every meal during the whole study period. Supplementary foods such as fruit and vegetables were introduced at 4 months and fish and meat at 5 months. The same method to record the consumption was used as previously described (6).

All infants were fed ad libitum and received 1000/IU vitamin A and 400 IU vitamin D daily. Protein contents in the formulas and the supplementary foods were provided by the manufacturer (10). These figures were used when protein intakes were calculated. When calculating the protein and energy intakes of each individual infant, a PC Commodore computer was used with a nutrition program, made by Soft Start Co. (based on Data Flex 
2.1) (including the nutrient content of the foods used in the study). The daily protein and energy intakes were expressed as previously described (6) in $\mathrm{g}$ of protein and $\mathrm{kcal} / \mathrm{kg}$ body weight (weight at the beginning of each study month).

Growth measurements. The measurements were performed by I.A. in the hospital at $4,4.5,5$, and 6 months. The naked child was weighed before feeding on an electronic scale (precision stated by the manufacturer is $\pm 1 \mathrm{~g}$ ). Crown-heel length and head circumference were measured using standard procedures (6). Rates of weight gain were calculated between 4-5 and 5-6 months, and expressed as $\mathrm{g} / \mathrm{kg}$ (kg at 4 months) per wk. Increments of length and head circumference were expressed as $\mathrm{mm} /$ $\mathrm{m}$ (meter at 4 months) per wk for the whole study period.

Biochemical analysis. Peripheral venous blood samples, 1.5$2 \mathrm{ml}$ were drawn immediately before feeding at $1000 \mathrm{~h}$, at 4,5 , and 6 months of age. Urine was collected at home during an 8$\mathrm{h}$ period in plastic bags. The serum, plasma, and urine samples were frozen at $-20^{\circ} \mathrm{C}$ until analyzed. Urea concentration in serum and in urine was determined according to Chaney and Morbach (11). Total nitrogen in urine was determined by the Kjeldahl method (12). Creatinine in urine was analyzed according to Haugen and Blegen (13). The concentration of sodium, potassium, calcium, and creatinine in serum were measured by standard laboratory methods. The content of albumin in serum was determined according to Pirell and Northam (14). Transferrin, prealbumin, and orosomucoid in plasma were analyzed by electroimmunoassay according to Laurell (15). Different solutions of Seronorm (Nyegaard and Co., Oslo, Norway) and used as standard. Samples from patients with high and low concentrations of the proteins were used as controls.

Statistics. F test of the equality of two variances was performed before the significance of the differences between groups were tested using Student's $t$ test. Between the different subjects linear regression was used. This study was approved by the Ethical Committee, University of Lund.

\section{RESULTS}

Clinical observation. All the infants had normal psychomotoric development. In three cases symptoms of mild infections such as gastroenteritis, conjunctivitis, bronchitis were observed and in two cases otitis was observed. The blood or urine samples taken during such periods were excluded and completed later. One child dropped out because of difficulties with the blood sampling.

Intakes. The mean breast milk intakes were 749 and $666 \mathrm{ml} /$ day during the first and second study month, respectively. The mean intakes of protein and calories from breast milk, formula, supplementary food, and the total intakes are given in Tables 1 and 2 . There were significant differences in total protein intake between the groups at 5 months (BF versus F1.3, $p<0.001, \mathrm{BF}$ versus $\mathrm{F} 1.8, p<0.001, \mathrm{~F} 1.3$ versus $\mathrm{F} 1.8, p<0.001)$ and at 6 months (BF versus $\mathrm{F} 1.3, p<0.01$, BF versus $\mathrm{F} 1.8, p<0.001$, F1.3 versus $\mathrm{F} 1.8, p<0.001)$. In each individual subject, weight gain correlated to protein intake $(r=0.43, p<0.01)$. No differences were found in total caloric intake when the two artificially fed groups were compared, but a significant difference was found when these two groups were tested against the $\mathrm{BF}$ infants at 5 months (BF versus F1.3, $p<0.001$, BF versus $\mathrm{F} 1.8$, $p<0.001$ ) and at 6 months (BF versus $\mathrm{F} 1.3, p<0.05$, BF versus $\mathrm{F} 1.8, p<0.01)$. The caloric and protein intakes from supplementary food did not differ between the groups (Tables 1 and 2).

Growth. The mean weight and length in the different feeding groups are given in Figure 1. The rate of weight gain in the infants fed human milk was $18.8 \pm 4.0$ and $17.3 \pm 7.1 \mathrm{~g} / \mathrm{kg} / \mathrm{wk}$ between 4-5 and 5-6 months, respectively. In the F1.3 group the weight gain was $20.9 \pm 6.5$ and $17.6 \pm 5.3 \mathrm{~g} / \mathrm{kg} / \mathrm{wk}$, respectively (Fig. 2). There was no statistically significant difference between these groups. In the F1.8 group the rate of weight gain was higher at both $4-5$ months, $26.1 \pm 7.5(p<0.01)$ and at 56 months $22.05 \pm 3.6 \mathrm{~g} / \mathrm{kg} / \mathrm{wk}(p<0.05)$, compared to the BF group (Fig. 2). The infants in the F1.8 group had a length growth of $7.6 \pm 2.2 \mathrm{~mm} / \mathrm{m} / \mathrm{wk}$, as compared to the $\mathrm{BF}(6.8 \pm 1.8)$ and the F1.3 group $(6.2 \pm 2.5)$. The differences were, however, not statistically significant. The increment for head circumference was almost the same in all groups $(\mathrm{BF}=5.6 \pm 1.5, \mathrm{~F} 1.3=5.6$ \pm 0.7 , and $F 1.8=5.2 \pm 1.1 \mathrm{~mm} / \mathrm{m} / \mathrm{wk}$ ).

Blood and urine chemistry. When entering the study the concentration of urea in serum was higher in the F1.8 group, $2.8 \pm$ $1.1 \mathrm{mmol} /$ liter, and in the F1.3 group, $3.4 \pm 1.3 \mathrm{mmol} / \mathrm{liter}$, compared to the BF group, $1.6 \pm 0.7 \mathrm{mmol} / \mathrm{liter}(\mathrm{BF}$ versus $\mathrm{F} 1.8$, $p<0.01, \mathrm{BF}$ versus $\mathrm{F} 1.3, p<0.001$ ). At 5 months serum urea was $1.8 \pm 0.7 \mathrm{mmol} /$ liter in the BF group and $2.5 \pm 0.7 \mathrm{mmol} /$ liter in the F1.3 group $(p<0.05)$ and at 6 months there was no significant difference, $2.2 \pm 0.7$ and $2.8 \pm 0.6 \mathrm{mmol} / \mathrm{liter}$,

Table 1. Mean intake of protein in BF infants and in F1.3 and F1.8 groups (mean \pm SD)

\begin{tabular}{|c|c|c|c|c|c|c|}
\hline \multirow[b]{2}{*}{ Group } & \multicolumn{2}{|c|}{$\begin{array}{l}\text { Protein from breast milk or } \\
\text { formula }\end{array}$} & \multicolumn{2}{|c|}{ Protein by supplementary food } & \multicolumn{2}{|c|}{ Total protein intake } \\
\hline & $4-5$ mo & $5-6 \mathrm{mo}$ & $4-5 \mathrm{mo}$ & $5-6 \mathrm{mo}$ & 4-5 mo & $5-6 \mathrm{mo}$ \\
\hline $\mathrm{BF}$ & $1.09 \pm 0.14$ & $0.90 \pm 0.21$ & $0.07 \pm 0.05$ & $0.50 \pm 0.25$ & $1.16 \pm 0.14$ & $1.39 \pm 0.20$ \\
\hline F1.3 & $1.72 \pm 0.40^{*}$ & $1.43 \pm 0.26^{*}$ & $0.16 \pm 0.12 \dagger$ & $0.46 \pm 0.28 \mathrm{NS}$ & $1.88 \pm 0.38^{*}$ & $1.89 \pm 0.30 \ddagger$ \\
\hline F1.8 & $2.58 \pm 0.27^{*,} \S$ & $2.01 \pm 0.36^{* .} \S$ & $0.11 \pm 0.10 \mathrm{NS}$ & $0.57 \pm 0.52 \mathrm{NS}$ & $2.70 \pm 0.29^{*} \S$ & $2.58 \pm 0.20^{* \cdot} \S$ \\
\hline
\end{tabular}

$* p<0.001$ when $\mathrm{BF}$ was compared to $\mathrm{F} 1.3$ and $\mathrm{F} 1.8$.

$\dagger p<0.05$ when $\mathrm{BF}$ was compared to $\mathrm{F} 1.3$ and $\mathrm{F} 1.8$.

$\ddagger p<0.01$ when $\mathrm{BF}$ was compared to $\mathrm{F} 1.3$ and $\mathrm{F} 1.8$.

$\S p<0.001$ when $\mathrm{F} 1.3$ was compared to $\mathrm{F} 1.8$.

Table 2. Mean intake of cal in BF infants and in F1.3 and F1.8 groups (mean $\pm S D$ )

\begin{tabular}{|c|c|c|c|c|c|c|}
\hline \multirow[b]{2}{*}{ Group } & \multicolumn{2}{|c|}{ Calories from breast milk or formula } & \multicolumn{2}{|c|}{ Cal by supplementary food } & \multicolumn{2}{|c|}{ Total caloric intake } \\
\hline & $4-5 \mathrm{mo}$ & $5-6 \mathrm{mo}$ & $4-5 \mathrm{mo}$ & $5-6 \mathrm{mo}$ & $4-5 \mathrm{mo}$ & $5-6 \mathrm{mo}$ \\
\hline $\mathrm{BF}$ & $73.62 \pm 9.30$ & $60.88 \pm 14.45$ & $6.34 \pm 4.64$ & $19.73 \pm 10.10$ & $79.96 \pm 10.75$ & $80.61 \pm 15.51$ \\
\hline F1.3 & $90.45 \pm 12.40^{*}$ & $79.79 \pm 13.76^{*}$ & $9.26 \pm 6.94 \mathrm{NS}$ & $15.89 \pm 9.46 \mathrm{NS}$ & $99.71 \pm 11.94 \dagger$ & $95.68 \pm 17.47 \ddagger$ \\
\hline F1.8 & $102.03 \pm 12.49+\S$ & $81.25 \pm 15.10^{*}$ & $6.20 \pm 5.90 \mathrm{NS}$ & $19.27 \pm 16.0 \mathrm{NS}$ & $108.23 \pm 14.48 \dagger$ & $100.52 \pm 7.15^{*}$ \\
\hline
\end{tabular}

$* p<0.01$ when $\mathrm{BF}$ was compared to $\mathrm{F} 1.3$ and $\mathrm{F} 1.8$.

$\dagger p<0.001$ when BF was compared to F1.3 and F1.8.

$\ddagger p<0.05$ when $\mathrm{BF}$ was compared to $\mathrm{F} 1.3$ and $\mathrm{F} 1.8$.

$\S p<0.05$ when $\mathrm{F} 1.3$ was compared to $\mathrm{F} 1.8$. 

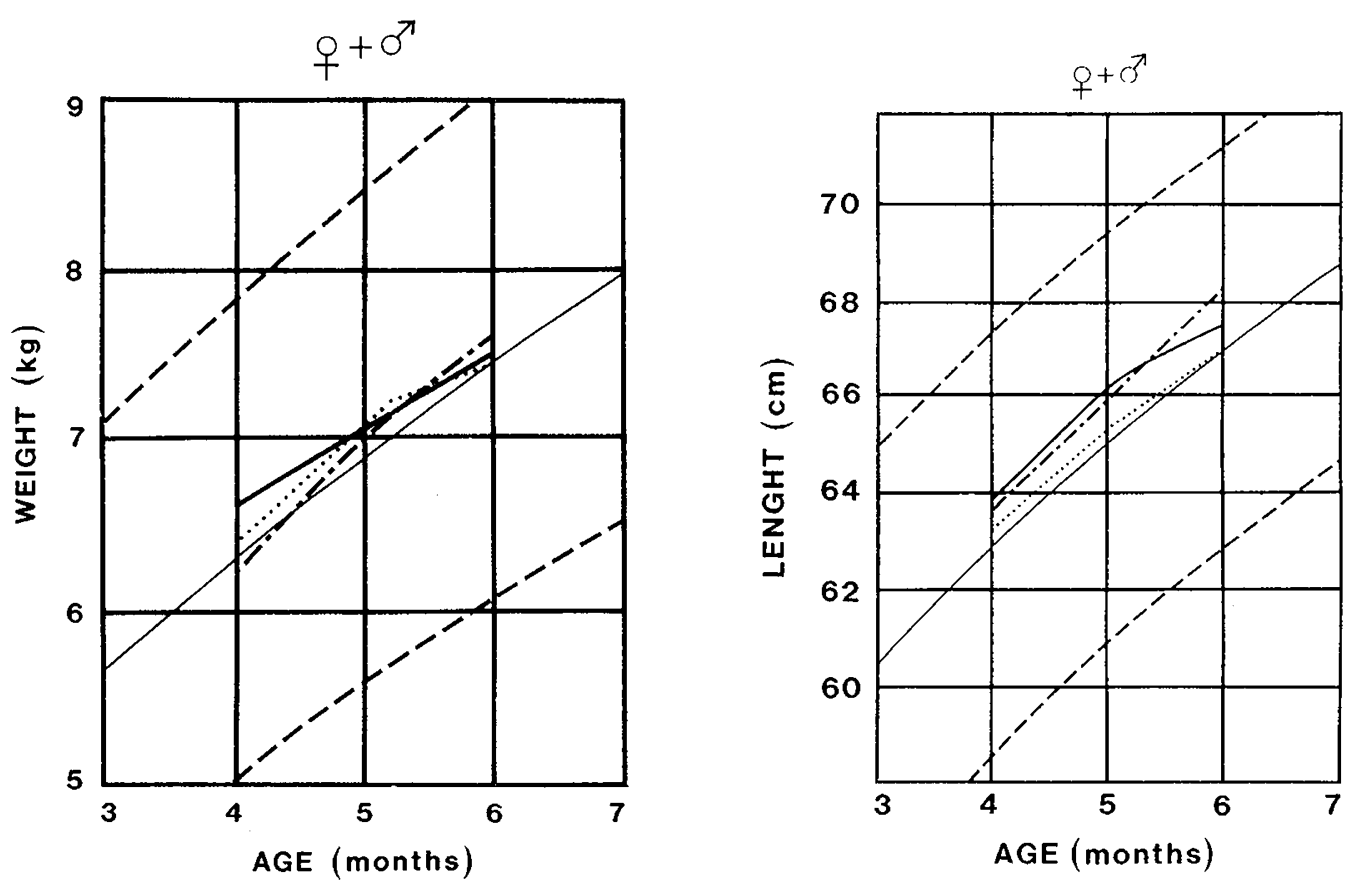

Fig. 1. Mean weight and length in the BF group _ _ F1.3 group ..., and F1.8 group — - -- from 4-6 months of age, superimposed on the Swedish growth charts (9) showing mean \pm 2 SD lines.

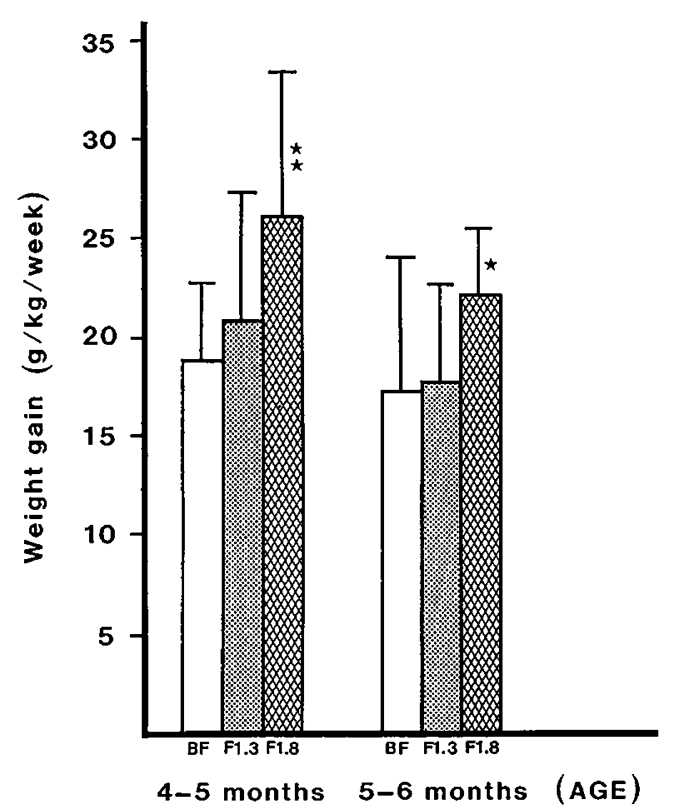

Fig. 2. Mean weight gain expressed as $\mathrm{g} / \mathrm{kg} / \mathrm{wk}$ in the $\mathrm{BF}, \mathrm{F} 1.3$, and F1.8 groups in relation to age. There were no differences between the $\mathrm{BF}$ and $\mathrm{F} 1.3$ groups, but between the $\mathrm{BF}$ and $\mathrm{F} 1.8$ groups from $4-5$ months $(p<0.01)$ and from 5-6 months $(p<0.05)$.

respectively (Fig. 3). In contrast the urea concentration was higher in the F1.8 group, at 5 months $4.2 \pm 1.1 \mathrm{mmol} /$ liter and at 6 months $4.1 \pm 0.7 \mathrm{mmol} / \mathrm{liter}$. When the $\mathrm{F} 1.8$ group was tested against the BF group and F1.3 group the urea concentration was significantly higher in the $\mathrm{F} 1.8$ group at 5 months (BF versus $\mathrm{F} 1.8, p<0.001, \mathrm{~F} 1.3$ versus $\mathrm{F} 1.8, p<0.001)$ and at 6 months (BF versus $\mathrm{F} 1.8, p<0.001, \mathrm{~F} 1.3$ versus $\mathrm{F} 1.8, p<0.001$ ).

The mean values for the excretion of urea and total nitrogen are given in Table 3. For both parameters the excretion was similar in the infants fed human milk and formula F1.3 at 6 months, but a significantly higher excretion was found in the infants fed formula F1.8 (BF versus F1.8, $p<0.05$ ). When the

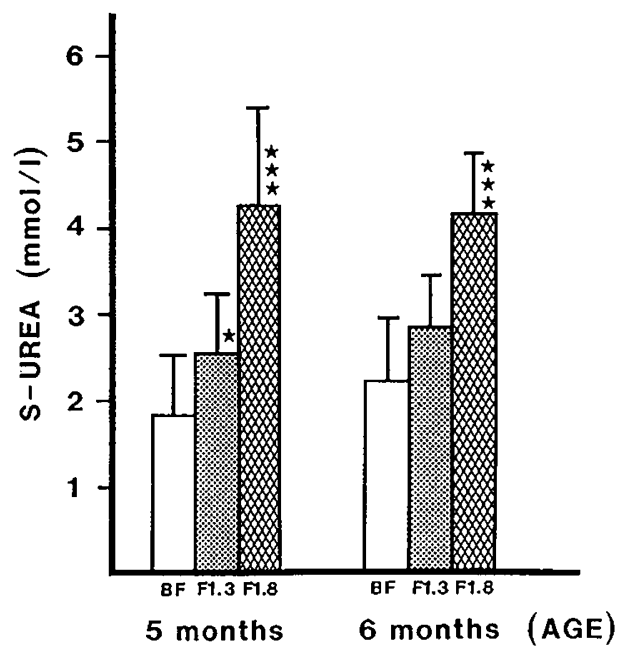

Fig. 3. Mean concentration of serum urea (nmol/liter) in the $\mathrm{BF}$, F1.3, and F1.8 groups in relation to age. At 5 months there was a difference between the $\mathrm{BF}$ and $\mathrm{F} 1.3$ groups $(p<0.05)$ and the $\mathrm{BF}$ and F1.8 groups $(p<0.001)$. At 6 months there was no difference between the BF and F1.3 groups, but between the BF and F1.8 groups the difference was $p<0.001$.

24-h urine excretion of nitrogen was extrapolated from the 8-h values the nitrogen excretion at 6 months was $78.6,80.6$, and $138.3 \mathrm{mg} / \mathrm{kg} /$ day in the BF, F1.3, and F1.8 groups, respectively.

The mean values for the plasma proteins albumin, prealbumin, and transferrin are given in Table 4 . All values were within the normal range for the age and no differences between the groups were found. The mean values for creatinine in serum were 38.1 $\pm 5.6,43.0 \pm 6.9$, and $44.3 \pm 9.1 \mu \mathrm{mol} / \mathrm{liter}$ and the excretion in urine $1.3 \pm 0.4,1.2 \pm 0.5$, and $1.8 \pm 1.5 \mathrm{mmol} /$ liter at 6 months in the BF, F1.3, and F1.8 groups, respectively. For these parameters there were no significant differences between the feeding groups. All the infants had normal values for potassium, sodium, and calcium in serum. Plasma amino acid levels and plasma and urine C-peptide concentrations will be reported in subsequent reports (16). 
Table 3. Mean excretion of total nitrogen and urea in urine in different feeding groups (mean $\pm S D$ )

\begin{tabular}{|c|c|c|c|c|c|c|}
\hline \multirow[b]{2}{*}{ Groups } & \multicolumn{2}{|c|}{ Total nitrogen/urine $(\mathrm{g} / 100 \mathrm{ml})$} & \multicolumn{2}{|c|}{$\begin{array}{l}\text { Nitrogen excretion/ } \\
\text { urine }(\mathrm{mg} / \mathrm{kg} / \text { day })^{*}\end{array}$} & \multicolumn{2}{|c|}{ Urea/urine (mmol/liter) } \\
\hline & $4 \mathrm{mo}$ & $6 \mathrm{mo}$ & $4 \mathrm{mo}$ & $6 \mathrm{mo}$ & $4 \mathrm{mo}$ & $6 \mathrm{mo}$ \\
\hline $\mathrm{BF}$ & $0.12 \pm 0.05$ & $0.19 \pm 0.04$ & 58.1 & 78.6 & $39.5 \pm 12.8$ & $58.3 \pm 8.7$ \\
\hline $\mathrm{F} 1.3$ & $0.24 \pm 0.08 \dagger$ & $0.20 \pm 0.06 \mathrm{NS}$ & 119.4 & 80.6 & $75.5 \pm 25.9 \dagger$ & $66.3 \pm 11.8 \mathrm{NS}$ \\
\hline F1.8 & $0.26 \pm 0.18$ & $0.35 \pm 0.19 \ddagger \S$ & 130.9 & 138.3 & $75.0 \pm 39.6 \dagger$ & $123.3 \pm 95.8 \ddagger$ \\
\hline
\end{tabular}

* Extrapolated from 8-h urine collections.

$\dagger p<0.01$ when $\mathrm{BF}$ was compared to $\mathrm{F} 1.3$ and $\mathrm{F} 1.8$.

$\ddagger p<0.05$ when $\mathrm{BF}$ was compared to $\mathrm{F} 1.3$ and $\mathrm{F} 1.8$.

$\S p<0.05$ when $\mathrm{F} 1.3$ was compared to $\mathrm{F} 1.8$.

Table 4. Concentration of plasma proteins in different feeding groups (mean $\pm S D)^{*}$

\begin{tabular}{|c|c|c|c|c|c|c|c|c|c|}
\hline \multirow[b]{2}{*}{ Group } & \multicolumn{3}{|c|}{ Albumin (g/liter) } & \multicolumn{3}{|c|}{ Prealbumin (g/liter) } & \multicolumn{3}{|c|}{ Transferrin (g/liter) } \\
\hline & $4 \mathrm{mo}$ & $5 \mathrm{mo}$ & $6 \mathrm{mo}$ & $4 \mathrm{mo}$ & $5 \mathrm{mo}$ & $6 \mathrm{mo}$ & $4 \mathrm{mo}$ & $5 \mathrm{mo}$ & $6 \mathrm{mo}$ \\
\hline $\mathrm{BF}$ & $44.1 \pm 3.9$ & $43.1 \pm 2.2$ & $42.9 \pm 4.1$ & $0.18 \pm 0.04$ & $0.16 \pm 0.04$ & $0.17 \pm 0.03$ & $2.5 \pm 0.75$ & $2.3 \pm 0.39$ & $2.6 \pm 0.36$ \\
\hline F1.3 & $42.5 \pm 1.8$ & $40.6 \pm 3.9$ & $42.4 \pm 1.9$ & $0.16 \pm 0.04$ & $0.18 \pm 0.03$ & $0.18 \pm 0.03$ & $2.3 \pm 0.36$ & $2.3 \pm 0.29$ & $2.5 \pm 0.27$ \\
\hline F1.8 & $43.0 \pm 3.2$ & $43.1 \pm 2.7$ & $43.6 \pm 3.9$ & $0.17 \pm 0.05$ & $0.18 \pm 0.03$ & $0.17 \pm 0.01$ & $2.2 \pm 0.44$ & $2.3 \pm 0.44$ & $2.5 \pm 0.38$ \\
\hline
\end{tabular}

* No significant differences among the groups.

\section{DISCUSSION}

Most weaning formulas currently used in Europe have a protein concentration between 1.8 and $2.5 \mathrm{~g} / 100 \mathrm{ml}$. The data from our previous studies, and those of others, during the weaning period have shown that protein intakes of artificially fed infants are two to three times higher than those of BF infants $(6$, 17). This high protein intake is reflected in metabolic parameters such as high serum urea levels, high concentrations of nitrogen and creatinine in urine, and high levels of most plasma amino acids $(7,8)$.

One of the main goals of nutritional assessment during the first 6 months of life is to attain a protein intake in artificially fed infants similar to that found in BF infants, without risk for deficiency. By reducing the protein concentration in a weaning formula from 1.8 to $1.3 \mathrm{~g} / 100 \mathrm{ml}$, the total protein intake has been reduced in the present study by $0.7 \mathrm{~g} / \mathrm{kg} /$ day from 2.6 to $1.9 \mathrm{~g} / \mathrm{kg} /$ day.

International recommendations such as made by the Canadian Report (18) and FAO/WHO/UNU (19) describe the safe level of protein intake as that obtained by the factorial method +2 $\mathrm{SD}$, a figure that might cover all but $2-3 \%$ of the individuals in the group. Between 3-6 months of life the calculated safe level has been suggested to be $1.86 \mathrm{~g}$ protein $/ \mathrm{kg} /$ day (19), a level corresponding to that found in our F1.3 group. This indicates that a healthy infant fed a formula with a protein content of 1.3 $\mathrm{g} / 100 \mathrm{ml}$ will theoretically not be at risk for protein deficiency.

From data concerning daily accretion of body protein plus inevitable losses of nitrogen using the factorial method, the requirement during this period of life is $1.15 \mathrm{~g} / \mathrm{kg} /$ day (5), i.e., the same level as that found in our BF group, and that reported by others for exclusively $\mathrm{BF}$ infants $(5,20)$.

Urea concentration in serum has been used to evaluate net protein use and quality of protein (21). In the present study the levels of serum urea correlate well with the protein intakes and weight gains. In the infants fed the low protein formula, the values were similar to those in the BF group at 6 months. The urinary excretion of urea and total nitrogen showed a similar pattern.

When the intake of protein is near the required level, the urinary excretion of nitrogen should be about $91 \mathrm{mg} / \mathrm{kg} /$ day according to Fomon (5). In the infants fed the F1.3, the excretion of nitrogen at 6 months was $81 \mathrm{mg} / \mathrm{kg} /$ day, near the level calculated by Fomon and that found in the BF infants. These findings give evidence of a nitrogen retention in the F1.3 group, comparable to that of the infants fed human milk. In contrast, the infants in the F1.8 group had significantly higher excretion of nitrogen, $138 \mathrm{mg} / \mathrm{kg} /$ day, which together with the levels of serum urea suggest an excessive nitrogen intake in relation to its use for growth in this age group of infants.

Several studies have indicated that a high protein intake may influence glomerular function both in experimental animals (22) and in children with moderately reduced glomerular filtration rate (23). Our present study confirms previous findings showing a relation between the excretion of creatinine in the urine and the protein intake (24). If the renal effects of a high protein diet in this age group has any lasting effects on renal function and development cannot be judged on the basis of these results.

Serum albumin has traditionally been a basic measure of protein nutritional status as it is usually decreased in protein malnourished patients (25). However, the relatively long half-life of 20 days limits its usefulness (26), and serum albumin differences were not expected in the present study. Other specific proteins that have been used for assessment of protein nutritional status include prealbumin and transferrin $(25,27)$. Prealbumin is a rapidly synthesized protein with a biologic half-life of $48 \mathrm{~h}$ (25) and considered to be a negative acute phase reactant. The concentrations of prealbumin and transferrin in plasma in all infants in this study were within the normal levels for the age group $(20,28)$. These findings suggest adequate protein nutrition in all infants.

The most important functional index of nutritional status is the growth pattern of a child. All infants in our study had a normal growth. The rate of weight gain in the BF group was the same as in the infants fed the F1.3. The major anthropometric difference between the groups was the higher weight gain in the F1.8 group of infants. The total energy intake did not differ in the two formula groups, thus it seems most probable that the increased weight gain in the F1.8 group is a result of a higher protein intake in these infants. A high protein intake gives elevated concentrations of the branched chain plasma amino acids (8) that effect insulin secretion (29). This could be a growthpromoting factor during infancy (16).

In conclusion, we state that during weaning the anthropometric and biochemical assessments of nutritional status studied were more like those found in $\mathrm{BF}$ infants when the protein content in the formula administered was reduced to a level more similar to that found in human milk. On the basis of these results 
we suggest that the protein content of cow's milk-based formulas used for normal healthy infants during the weaning period should be reduced to approximately $1.3 \mathrm{~g} / 100 \mathrm{ml}$.

Acknowledgments. The authors thank the Findus and Nordreco Companies, Bjuv, Sweden, for their support and for the careful preparation of the formulas and supplementary foods used.

\section{REFERENCES}

1. Hamosh M 1988 Does infant nutrition affect adiposity and cholesterol levels in the adult? J Pediatr Gastroenterol 7:10-16

2. Järvenpää A-L, Räihä NCR, Rassin DK, Gaull GE 1982 Milk protein quantity and quality in the term infant. I. Metabolic responses and effects on growth Pediatrics 70:214-220

3. Räihä NCR, Minoli I, Moro G 1986 Milk protein intake in the term infant. I. Metabolic responses and effects on growth. Acta Paediatr Scand 75:881-886

4. Janas LM, Picciano MF, Hatch TF 1985 Indices of protein metabolism in term infants fed human milk, whey predominant formula, or cow's milk formula. Pediatrics 75:775-784

5. Fomon SJ 1986 Protein requirements of term infants. In: Fomon SJ, Heird WC (eds) Energy and Protein Needs during Infancy. Academic Press, Inc., New York, pp 55-68

6. Axelsson I, Borulf S, Righard L, Räihä N 1987 Protein and energy intake during weaning. I. Effects on growth. Acta Paediatr Scand 76:321-327

7. Axelsson I, Borulf S, Räihä N 1987 Protein intake during weaning. II. Metabolic responses. Acta Paediatr Scand 76:457-462

8. Axelsson I, Borulf S, Abildskov K, Heird W, Räihä N 1988 Protein and energy intake during weaning. III. Effects on plasma amino acids. Acta Paediatr Scand 77:42-48

9. Karlberg P, Taranger J, Engström I, Lichtenstein H, Svennberg-Redegren I 1976 The somatic development of children in a Sweden urban community. Acta Paediatr Scand [Suppl] 258:7-76

10. Codex Alimentarius 1984 IX ed, $1: 41$

11. Chaney AL, Morbach EP 1962 Modified reagents for determination of urea and ammonia. Clin Chem 8:130-132

12. Hambraeus L, Forsum E, Abrahamsson L, Lönnerdal B 1976 Automatic total nitrogen analysis in nutritional evaluations using a block digestion. Anal Biochem 72:78-85

13. Haugen HN, Blegen EM 1953 True endogenous creatinine clearance. Scand J
Clin Lab Invest 5:67-71

14. Pirell AE, Northam BE 1978 New automated dye binding method for serum albumin determination with bromcresol purple. Clin Chem 24:80-86

15. Laurell C-B 1972 Electroimmunoassay. Scand J Clin Lab Invest [Suppl] 124:21-37

16. Axelsson I, Ivarsson S, Räihä N Protein intake during weaning: effect on insulin metabolism. Pediatr Res (in press)

17. Horst CH, Obermann-de Boer GL, Kromhout D 1987 Type of milk feeding and nutrient intake during infancy. Acta Paediatr Scand 76:865-871

18. Ad Hoc Consultative Group on the Dietary Standard for Canada: Recommended Nutrient Intakes for Canadians. Health and Welfare Canada, Ottawa, 1983

19. Technical Report Series no. 724. Report of a Joint FAO/WHO/UNU Expert Consultation. Energy and Protein Requirements. Geneva, 1985, pp 98-112

20. Salmenperä L, Perheentupa J, Siimes M 1985 Exclusively breastfed healthy infants grow slower than reference infants. Pediatr Res 19:307-312

21. Jansen GR 1981 Biochemical Parameters and Protein Quality. In: Bodwell CE, Adkins JS (ed) Protein Quality in Humans. Westport, pp 118-147

22. Jakobsson B, Celsi G, Lindblad BS, Aperia A 1987 Influence of different protein intake on renal growth in young rats. Acta Paediatr Scand 76:293299

23. Berg U, Bohlin A-B, Aperia A 1987 Short-term effect of low and high protein intake on renal function in children with renal disease. Acta Paediatr Scand 76:288-292

24. Rassin DK, Gaull GE, Räihä NCR, Heinonen K, Järvenpää A-L 1986 Protein quantity and quality in term and preterm infants: effects on urine creatinine and expression of amino acid excretion data. J Pediatr Gastroenterol Nutr 5:103-110

25. Yoder MC, Anderson DC, Gopalakrishna GS, Douglas SD, Polin RA 1987 Comparison of fibronectin, prealbumin and albumin concentrations during nutritional repletion in protein-calorie malnourished infants. J Pediatr Gastroenterol Nutr 6:84-88

26. Rassin DK 1987 Evaluation of protein nutritional status. J Pediatr Gastroenterol Nutr 6:7-9

27. Puri S, Chandra RK 1985 Nutritional regulation of host resistance and predictive value of immunologic tests in assessment of outcome. Pediatr Clin North Am 32:499-516

28. Vahlquist A, Rask L, Peterson PA, Berg T 1975 The concentrations of retinolbinding protein, prealbumin, and transferrin in the sera of newly delivered mothers and children of various ages. Scand J Clin Invest 35:569-575

29. Christensen HN, Hellman B, Lernmark A 1971 In vitro stimulation of insulin release by non-metabolizable transport specific amino acids. Biochem Biophys Acta 241:341-348 